einstein

Official Publication of the Instituto Israelita de Ensino e Pesquisa Albert Einstein

ISSN: 1679-4508 | e-ISSN: 2317-6385
How to cite this article:

Correa-Arruda WS, Vaez IA, Aguilar-Nascimento JE, Dock-Nascimento DB. Reply to: Is muscular strength compromised by overnight fasting or food ingestion in hospital settings? [letter] einstein (São Paulo). 2019;17(4):eCE5406. http://dx.doi.org/10.31744/einstein journal/ 2019CE5406

\section{Copyright 2019}

\section{(cc)}

This content is licensed

under a Creative Commons

Attribution 4.0 International License.
AUTHORS' REPLY

Reply to: Is muscular strength compromised by overnight fasting or food ingestion in hospital settings?

\author{
Resposta para: A força muscular é comprometida pelo jejum \\ noturno ou pelo percentual de ingestão da dieta hospitalar? \\ Wesley Santana Correa-Arruda', lara dos Anjos Vaez', \\ José Eduardo de Aguilar-Nascimento', Diana Borges Dock-Nascimento' \\ ${ }^{1}$ Graduate Program in Health Sciences, Universidade Federal de Mato Grosso, Cuiabá, MT, Brazil.
}

DOI: 10.31744/einstein_journal/2019CE5406

Initially, we are grateful for the considerations made by Rodrigues et al. The central idea of the study was to investigate if overnight fasting, often required for surgical or diagnostic procedures, has an impact on muscle function. Doubtless, the findings showed that the 8-hour night fasting, although physiological, resulted in decreased functional capacity determined by dynamometry. This is aggravated by the fact that fasting for procedures in Brazilian hospitals, prescribed for 8 hours, is really longer, and is estimated at up to 18 hours, on average, sometimes reaching 24 hours, in some cases. ${ }^{(1)}$ This is relevant, and the findings showed that muscle function may be hindered when this prolonged fasting is during the day, ${ }^{(2)}$ considering that the patient is awake and in greater metabolic stress. ${ }^{(3)}$ Another important point in our findings is that muscle strength increased according to the quantity of the evening meal consumed the night before the measurement of strength and after breakfast and lunch. This showed a positive interference of the ingestion of calories and nutrients on muscle function. These results reinforced the need to guarantee that the patients ingest or receive, via nutritional therapy, all their nutritional needs, ${ }^{(4)}$ and that the fasting time for procedures, tests, or surgeries, as per recommendation of the ACERTO project, ${ }^{(5)}$ be reduced. ${ }^{(6)}$ Thus, just as fasting may result in reduced muscle strength, leading to worse clinical outcomes, ${ }^{(7)}$ and the ingestion of food improved this muscle capacity, in daily routine, it is necessary to reduce fasting time and guarantee a greater ingestion of calories and nutrients to the patients. The inclusion of tables and figures aimed only to give the readers a quicker view of the findings which, as you yourselves recorded, are relevant. Finally the odds ratio also gives the reader an idea of the chance of an event occurring, and this adds information - oftentimes, greater than only the $\mathrm{p}$ value. Hence, we believe the conclusions were consistent with the objectives established and the results obtained. We hope these considerations help the authors and the readers better understand the original article published by the journal einstein.

\section{AUTHORS' INFORMATION}

Correa-Arruda WS: http://orcid.org/0000-0002-2163-2678

Vaez IA: http://orcid.org/0000-0003-0014-4592

Aguilar-Nascimento JE: http://orcid.org/0000-0002-3583-6612

Dock-Nascimento DB: http://orcid.org/0000-0003-0205-6676 


\section{REFERENCES}

1. Aguilar-Nascimento JE, Dias AL, Dock-Nascimento DB, Correia Ml, Campos AC, Portari-Filho PE, et al. Actual preoperative fasting time in Brazilian hospitals: the BIGFAST multicenter study. Ther Clin Risk Manag. 2014;10:107-12.

2. Franklin GA, McClave SA, Hurt RT, Lowen CC, Stout AE, Stogner LL, et al. Physician-delivered malnutrition: why do patients receive nothing by mouth or a clear liquid diet in a university hospital setting? JPEN J Parenter Enteral Nutr. 2011;35(3):337-42.

3. Nygren J. The metabolic effects of fasting and surgery. Best Pract Res Clin Anaesthesiol. 2006;20(3):429-38. Review.
4. Ostrowska J, Jeznach-Steinhagen A. Fight against malnutrition (FAM): Selected results of 2006-2012 nutrition day survey in Poland. Rocz Panstw Zakl Hig. 2016;67(3):291-300.

5. Bicudo-Salomão A, Meireles MB, Caporossi C, Crotti PL, Aguilar-Nascimento JE. Impact of the acerto project in the postoperative morbi-mortality in a university hospital. Rev Col Bras Cir. 2011;38(1):3-10.

6. Kondrup J. Can food intake in hospitals be improved? Clin Nutr. 2001;20(Supl 1): $153-60$.

7. Humphreys J, de La Maza P, Hirsh S, Barrera G, Gattas V, Bunout D. Muscle strength as a predictor of loss of functional status in hospitalized patients. Nutrition. 2002;18(7-8):616-20. 